\title{
KEDUDUKAN ORGANISASI KEMASYARAKATAN ASING DI INDONESIA DI TINJAU DARI PERATURAN PEMERINTAH NOMOR 59 TAHUN 2016*
}

\author{
*Elwidarifa Marwenny ${ }^{1}$, Engrina Fauzi ${ }^{2}$ dan Jelisye Putri Cenery ${ }^{3}$ \\ Universitas Dharma Andalas Padang, \\ Simpang Lalang, Tabing-Padang, Sumatera Barat ${ }^{1}$ \\ e-mail: elwidarifamarwenny@ gmail.com \\ Jalan Sawahan No.103A Simpang Haru, Padang, Sumatera Barat ${ }^{2}$ \\ e-mail: engrinafauzi@gmail.com \\ Jl. Sawahan No. 103 A, Simpang Haru Padang ${ }^{3}$ \\ e-mail:pjelisye@yahoo.com
}

\begin{abstract}
One of the form of applying the value of democratic in Indonesia is accommodate by the regulation of community organization which is concretely regulated in the provisions of article $28 E$ Paragraph 3 of the 1945 constitution also in the provisions of law number 39 of 1999 on Human Rights. The existence of community organizations does have a great constribution in the implementation of the state, but on the other hand the existence of people raises the pro and contra. The enecment of government regulation number 59 on community organization established by foreign citizens makes the community more worried if the exixtance of community organizations affect the sovereignty of NKRI because they have different ideology with Indonesia. Based on this, it should be discussed about the organizations in Indonesia. The position of foreign social organizatios in Indonesia is reviwed from the government regulation number 59 of 2016 on community organizations established by foreign citizens and the influence of basic organizations for the sovereignty of NKRI. To answer that question, qualitative method is used as a means to answer the problem by conducting of normative juridical approach which is done by reviewing the law and the literature. Based on this study, it is concluded that the existence of foreign social organizatios in Indonesia in line with democracy and human right but also politically can treaten NKRI.
\end{abstract}

Keyword: citizen organization, democracy, human right

\section{Abstrak}

Salah satu bentuk penerapan nilai-nilai demokrasi Indonesia tercermin dari adanya pengaturan mengenai organisasi masyarakat yang secara kongkret diatur dalam ketentuan Pasal 28 E ayat (3) Undang-undang Dasar 1945 juga dalam ketentuan Undang-Undang Nomor 39 tahun 1999 tentang Hak Asasi Manusia. Keberadaan organisasi masyarakat memang memiliki konstribusi besar dalam penyelenggaraan negara, namun di sisi lain menjadi hal yang cukup mengkhawatirkan bagi masyarakat sehingga menimbulkan pro dan kontra. Di sahkannya Peraturan pemerintah No. 59 tentang Organisasi masyarakat yang didirikan warga negara asing membuat masyarakat semakin khawatir jika keberadaannya berdampak terhadap kedaulatan NKRI karena berbeda ideologi. Berdasarkan hal tersebut diatas perlu kiranya dibahas tentang: pengaturan tentang organisasi ke masyarakat di Indonesia, kedudukan Organisasi Kemasyarakatan asing di Indonesia ditinjau dari Peraturan Pemerintah Nomor 59 Tahun 2016 tentang Organisasi Kemasyarakatan yang didirikan oleh warga negara asing dan pengaruh ormas asing bagi kedaulatan NKRI. Untuk menjawab pertanyaan tersebut, penulis menggunakan metode kualitatif dengan melakukan pendekatan yuridis normative dengan cara mengkaji Undang-undang dan literature, kemudian ditarik kesimpulan bahwasanya melegitimasi keberadaan ormas asing di Indonesia sejalan dengan demokrasi dan HAM namun secara politik juga dapat mengancam kedaulatan NKRI.

Kata kunci: Ormas, Demokrasi dan HAM

${ }^{*}$ Naskah diterima: 03 Maret 2018, direvisi:10 Maret 2018, disetujui untuk terbit: 26 Maret 2018 


\section{PENDAHULUAN}

Sebagai negara hukum, segala perbuatan yang dilakukan oleh negara haruslah didasarkan atas hukum (rechtstaat) dan bukan didasarkan atas kekuasaan semata (manchstaat). Hal ini tertuang dalam ketentuan UndangUndang Dasar Negara Republik Indonesia Tahun 1945 yakni dalam pasal 1 ayat 3 . Konsep Negara hukum Indonesia ini menghendaki bahwasanya hukum sebagai panglima tertinggi di dalam Negara, atau bisa juga dikatakan bahwasanya hukum merupakan poros segala perbuatan yang ada dalam Negara.

Keberadaan Negara hukum Indonesia, tidak bisa dilepaskan dari bentuk pemerintahan yang dianutnya yakni demokrasi. Demokrasi dalam artian Negara hukum adalah kebebasan yang bertanggung jawab, yaitu yang tetap menjadikan hukum sebagai acuan dasar dalam bertindak. Negara Indonesia memiliki kedaulatan penuh dalam penyelenggaraan pemerintahan yang menjadikan hukum sebagai dasar penyelenggaraan negaranya.

Organisasi masyarakat merupakan salah satu tanda bahwa suatu negara menerapkan prinsip demokrasi dan Hak Asasi Manusia karena dalam organisasi masyarakat mengenal adanya hak kebebasan berserikat (freedom of association), berkumpul (freedom of assembly) dan mengeluarkan pendapat (freedom of expression), dimana ketiga kebebasan tersebut merupakan konsep- konsep yang terdapat di dalam Hak Asasi Manusia. ${ }^{1}$

Kebebasan untuk berorganisasi di Indonesia terdapat juga dalam ketentuan Pasal 28 E ayat (3) Undang-undang Dasar 1945 yang menyatakan bahwa "Setiap orang berhak atas kebebasan berserikat, berkumpul, dan mengeluarkan pendapat”, kemudian Undang-Undang Nomor 39 tahun 1999 tentang Hak Asasi Manusia juga menyatakan bahwa "setiap orang berhak untuk berkumpul, berapat, dan berserikat untuk maksud-maksud damai". Kebebasan tersebut di ataslah yang menjadi dasar bagi masyarakat untuk membuat suatu wadah agar dapat menyalurkan aspirasinya serta berperan aktif dalam penyelenggaraan negara dan pemerintahan dengan membentuk organisasi masyarakat. Wujud partisipasi masyarakat ini yang merupakan suatu upaya konkret dalam pengembangan demokrasi untuk dapat menjunjung tinggi kebebasan, kesetaraan, kebersamaan, dan kejujuran yang merupakan implementasi dalam menerapkan Hak Asasi Manusia. ${ }^{2}$ Interaksi yang dilakukan oleh ormasormas yang memiliki kepentingan yang beragam ini yang akan menjadi suatu acuan dan dasar dalam menentukan arah dan kebijakan serta interaksi politik yang dipakai dalam negara Indonesia yang

Catur Wibowo dan Herman Harefa, Urgensi Pengawasan Organisasi Kemasyarakatan oleh Pemerintah, Jurnal Bina Praja, Volume 7 Nomor 1 Edisi Maret 2015. hlm.1 - 20 tersedia di www.unigal.ac.id/ejurnal/html/index.php?naon=1 052, di akses tanggal 01 Mei 2017

${ }^{2}$ Ibid. di akses tanggal 01 Mei 2017 
majemuk ini. ${ }^{3}$ Organisasi masyarakat di Indonesia diharapkan mampu menampung serta mewujudkan kepentingan bersama yang berazaskan pancasila, sehingga semua masyarakat mendapatkan manfaat yang rill dari keberadaan ormas. $^{4}$ Dalam sejarahnya, tidak dapat di pungkiri bahwasanya, ormas memang memiliki konstribusi besar dalam penyelenggaraan negara, namun di lain sisi keberadaannya juga menimbulkan banyak kekhawatiran sehingga muncul berbagai macam pro dan kontra.

Berdasarkan data yang dapat dikumpulkan dari beragam reference (sumber primer maupun sekunder) terdapat beberapa fakta mengenai keberadaan Ormas dalam masyarakat diantaranya:

1) Kamis, 09 Desember 2010, di Jakarta Polisi menyita puluhan senjata antar kampung setelah berhasil membubarkan bentrokan yang terjadi antar kelompok pria yang berpakaian dengan tulisan Forum Betawi Rempug (FBR) dan ormas kepemudaan disebabkan penarikan

3 Putu Indah Prameswari, Studi Kasus Tentang Organisasi Masyarakat Dalam Pemilihan Gubernur Bali 2013, tersedia di http://journal.unair.ac.id/download-fullpapersjpm3247d10b50full.pdf, di akses tanggal 1 Mei 2017

${ }^{4}$ Laporan Pengkajian Hukum Tentang Peran Dan Tanggungjawab Organisasi Kemasyarakatan Dalam Pemberdayaan Masyarakat, Pusat Penelitian Dan Pengembangan Sistem Hukum Nasional Badan Pembinaan Hukum Nasional Kementerian Hukum Dan Hak Asasi Manusia Ri Tahun 2011, tersedia di http://www.bphn.go.id/data/documents/pkj-20111.pdf, di akses tanggal 1 Mei 2017 mobil yang belum melunasi cicilan. Bentrokan ini menyebabkan sejumlah kerugian yaitu terdapatnya tiga unit mobil yang diparkir di depan Kantor PT Oto Multiara mengalami kerusakan.

2) Proses pelaksanaan sidang kasus pembunuhan di pengadilan Negeri Gianyar terpaksa ditunda disebabkan situasi memanas karena dua ormas yang saling bersiteru terus datang ke pengadilan. Sipelakau dan korban merupakan bagian dari dua ormas yang seling bersiteru tersebut. ${ }^{5}$

Keberadaan ormas dalam negeri sendiri bagi masyarakat begitu mengkhawatirkan, apalagi ormas asing. Keberadaan ormas asing dinilai akan menimbulkan Pro dan kontra. Sebagian masyarakat beranggapan bahwasanya ormas asing berbahaya bagi kedaulatan NKRI sedangkan sebagian lagi beranggapan itu merupakan perwujudan dari adanya hak kebebasan berserikat dan berorganisasi.

Rancangan Undang-undang tentang ormas mulai dibahas oleh DPR Pada tahun 2012 agar ada payung hukum yang dapat dijadikan dasar untuk mengatur ormas di Indonesia agar tidak menimbulkan gangguan keamanan di masyarakat. Sejalan dengan ini, ormas asing juga jadi kekhawatiran tersendiri

\footnotetext{
5 Catur Wibowo dan Herman Harefa, URGENSI PENGAWASAN ORGANISASI KEMASYARAKATAN OLEH PEMERINTAH , Badan Penelitian dan Pengembangan (BPP) Kementerian Dalam Negeri tersedia di https://media.neliti.com/media/publications/52270 -ID-urgensi-pengawasan-organisasikemasyarak.pdf, diakses tanggal 22 Agustus 2017
} 
Elwidarifa Marwenny, Engrina Fauzi, dan Jelisye Putri Cenery: Kedudukan...

karna itulah keberadaannya perlu ditekankan untuk sejalan dengan idiologi Pancasila.

Setelah keluarnya Peraturan Pemerintah (PP) Nomor 59 Tahun 2016 tentang Organisasi Masyarakat (Ormas) yang didirikan warga negara asing (WNA) muncul, persoalan ormas kembali mengemuka. Meskipun Wakil Presiden Jusuf Kalla menyatakan bahwasanya masyarakat tidak perlu khawatir dengan keberadaan PP ini karena pemerintah akan tetap memberikan sanksi sekiranya melanggar ketentuan undang-undang, namun masyarakat tetap saja tidak dapat menerimanya karena ditakutkan keberadaan ormas asing di Indonesia membawa agenda terselubung yang merugikan Indonesia. ${ }^{6}$ PP Nomor 59 Tahun 2016 tentang Organisasi Masyarakat (Ormas) tersebut menyebutkan bahwasanya ormas asing yang dapat melakukan kegiatan di wilayah Indonesia adalah badan hukum yayasan asing atau sebutan lain, badan hukum yayasan yang didirikan oleh warga negara asing bersama warga negara Indonesia, atau badan hukum yayasan yang didirikan oleh badan hukum asing.

Dalam PP ini diatur mengenai, pemberian perizinan, tim perizinan, dan pertimbangan pengesahan badan hukum, serta tata cara pengenaan sanksi bagi ormas berbadan hukum yayasan asing atau sebutan lain. PP ini mendapat tanda tangan presiden pada 2 Desember 2016

6 Waspadai Ormas Asing, tersedia di http://www.republika.co.id/berita/koran/fokuspublik/16/12/30/oizqc625-waspadai-ormas-asing, di akses tanggal 22 Agustus 2017 dimana ormas ini terdiri atas badan hukum yayasan asing atau sebutan lain yang mengelola dana secara mandiri dan badan hukum yayasan asing atau sebutan lain yang melaksanakan program kegiatan dari lembaga donor asing. Dalam PP ini dijelaskan bahwasanya organisasi yang didirikan oleh warga negara asing ini dapat mengajukan penugas kepada 3 orang yang memiliki 3 kewarganegaraan asing untuk bekerja pada ormas asing ini. Meskipun perjanjian tertulis dan ketentuan bahwasanya mereka harus tunduk pada peraturan perundangundangan harus dilaksanakan namun kekhawatiran masyarakat masih tetap ada. Seorang guru besar dari Universitas Indonesia Maswadi Rauf mempertanyakan alasan Jokowi memberikan izin untuk orang asing agar dapat mendirikan ormas di Indonesia sedangkan ideologinya berbeda, Maswadi mengkhawatirkan timbulnya bahaya dalam ketahanan Indonesia yang menurutnya masih lemah terhadap ancaman dari luar. ${ }^{7}$

Pengamat politik Uchok Sky Khadafi berpendapat bahwsanya ormas asing akan merugikan ormas-ormas yang ada di Indonesia, karena selalu menerima bantuan dari negaranya. Kekhawatiran lain yang dimiliki oleh uchock adalah munculnya paham garis keras yang akan masuk ke Indonesia. ${ }^{8}$ Dari berbagai

http://www.voa-islam.com/read/politikindonesia/2016/12/19/47976/jokowi-tandatanganipp-59/2016-tentang-ormas-yang-didirikan-

wna/\#sthash.34OxsMH0.dpbs, di akses tanggal 22 Agustus 2017

http://www.voa-islam.com/read/politikindonesia/2016/12/19/47976/jokowi-tandatangani- 
kekhawatiran diatas, masyarakat memiliki ketakutan yang sama bahwasanya akan muncul paham-paham baru di Indonesia yang radikal ataupun paham komunis yang bertentangan dengan pancasila yang pada akhirnya mengancam kedaulatan negara Indonesia. Sementara jumlah ormas asing di Indonesia terus mengalami peningkatan. Saat ini ada 62 Ormas (International Non Governmental Organization/INGO) yang terdaftar di Kementerian Luar Negeri. ${ }^{9}$ Per tahun 2016, ada 67 ormas asing terdaftar di Kementerian Luar Negeri (Kemlu) dan sebaran ormas paling banyak ada di daerah Jawa Barat. ${ }^{10}$

\section{METODE PENELITIAN}

Metode yang digunakan dalam penulisan ini adalah kualitatif dengan pendekatan yuridis normatif dengan melakukan studi kepustakaan agar dapat menemukan konsep-konsep, pendapatpendapat ataupun tulisan-tulisan ilmiah yang relevan dengan topik penelitian yang di bahas agar dapat mengidentifikasi, menelaah persoalan-persoalan untuk menemukan ide, solusi terkait dengan persoalan yang dibahas.

pp-59/2016-tentang-ormas-yang-didirikan-

wna/\#sthash.34OxsMH0.dpbs, di akses tanggal 22 Agustus 2017

${ }^{9}$ ttp://www.kemendagri.go.id/news/2016/12/

20/pp-59-perketat-berdirinya-ormas-asing-diindonesia

${ }^{10} \mathrm{https} / / /$ news.detik.com/berita/d3379374/kemlu-ada-67-ormas-asing-di-indonesiaper-akhir-2016-terbanyak-di-jabar DI AKSES TANGGAL 20 Agustus 2017

\section{HASIL DAN PEMBAHASAN}

\section{Pengertian Organisasi Masyarakat}

Dalam bukunya Roocmulyati Hamzah yang berjudul Pengembangan Organisasi (2004:2), organisasi adalah suatu sistem yang terdiri dari pola aktivitas kerja sama yang dilakukan secara teratur dan berulang-ulang oleh sekelompok orang untuk mencapai tujauan tertentu. ${ }^{11}$ Dalam Undang-Undang Republik Indonesia Nomor 17 tahun 2013 tentang Organisasi Masyarakat bahwa yang dinamakan Organisasi Masyarakat (Ormas) adalah organisasi yang didirikan dan dibentuk oleh masyarakat secara sukarela berdasarkan kesamaan aspirasi, kehendak, kebutuhan, kepentingan, kegiatan dan tujuan untuk berpartisipasi dalam pembangunan demi tercapainya tujuan Negara Kesatuan Republik Indonesia yang berdasarkan Pancasila.

\section{Negara Hukum Indonesia}

Berdasarkan sejarah ketatanegaraan Indonesia, konsep negara hukum sudah lama dipakai meskipun dalam perjalanannya struktur ketatanegaraan Indonesia senantiasa berubah sesuai dengan perkembangan masyarakat sehingga membawa pengaruh kedalam pembentukan hukumnya. Dalam UUD 1945 dinyatakan dalam Pasal 1 ayat (3) secara tegas bahwa Indonesia memang merupakan negara hukum sehingga semakin mengukuhkan konsep bahwa Indonesia merupakan negara hukum.

\footnotetext{
11 e-Journal Ilmu Pemerintahan, 4 (1) 2016: 428-441 ISSN 2477-2631, ejournal.ip.fisipunmul.org (C) Copyright 2016
} 
Negara hukum Indonesia mengarah kepada Negara hukum Eropa Kontinental yang dipelopori oleh Immanuel Kant: ${ }^{12}$ terdiri dari adanya perlindungan terhadap HAM, adanya Pemisahan kekuasaan dalam negara. Kemudian unsur-unsur negara hukum tersebut ditambah oleh Stahl: ${ }^{13}$ bahwa Setiap tindakan negara harus berdasarkan undang-undang dan adanya Peradilan Administrasi untuk menyelesaikan perselisihan.

\section{Teori Demokrasi}

Demokrasi berasal dari kata demos dan kratos, demos adalah rakyat, sedangkan kratos/kratein berarti kekuasaan/berkuasa, istilah lain adalah government or rule by the people”. Istilah lain demokrasi yaitu demokrasi konstitusionil, demokrasi parlementer, demokrasi terpimpin, demokrasi pancasila, demokrasi rakyat, demokrasi soviet, demokrasi nasional, dan lain sebagainya. $^{14}$ Subandi Almarsudi mengatakan istilah demokrasi sebagai demos yang berarti rakyat dan cratein yang berarti pemerintah, yang memiliki makna bahwasanya pemerintahan rakyat ${ }^{15}$ dalam arti kata apabila ke kekuasaan negara berada di tangan rakyat, maka

\footnotetext{
12 Megawati, Ali Murtopo, 2006, Parlemen Bikameral dalam Sistem ketatanegaraan Indonesia, UAD Press, Yogyakarta, Hlm. 23

${ }^{13}$ Megawati, Ali Murtopo, 2006, Parlemen Bikameral dalam sistem ketatanegaraan Indonesia, UAD Press, Yogyakarta, Hlm. 23

14 Miriam Budiardjo, 2007, Dasar-dasar Ilmu Politik, PT Gramedia Pustaka Utama, Jakarta, Hlm. 50

${ }^{15}$ Subandi Almarsudi, 2001, Pancasila dan UUD 1945 dalam Paradigma Reformasi, PT. Raja Grafindo Persada, Jakarta, Hlm. 81
}

bentuk pemerintahannya merupakan demokrasi.

Bentuk-bentuk pemerintahan negara demokrasi terdiri dari: Pertama, Demokrasi Langsung dimana semua masyarakatnya ikut memilih dan ikut serta dalam pemerintahan. Contoh, negara Yunani, New England, dan negara-negara bagian Swiss (Appenzell, Glarus, Uri dan Unterwalden). Kedua, demokrasi perwakilan yaitu dengan memilih wakil yang duduk di parlemen dan parlemenlah yang kemudian memilih pemerintahnya, contoh negara demokrasi perwakilan, USA dengan parlemen, Indonesia dengan DPR. ${ }^{16}$

Di Indonesia, keberadaan demokrasi sudah mulai terlihat ditegaskan dalam naskah Pembukaan UUD 1945 yaitu "Kemerdekaan itu ialah hak segala bangsa", artinya setiap orang memiliki kebebasan untuk lepas dari segala bentuk penindasan. Pada alinea ketiga juga ditegaskan bahwa rakyat Indonesia menyatakan kemerdekaannya "supaya berkehidupan kebangsaan yang bebas". ${ }^{17}$

Demokrasi yang dianut di Indonesia, yaitu demokrasi berdasarkan pancasila, masih dalam taraf perkembangan dan mengenai sifat-sifat dan ciri-cirinya terdapat berbagai penafsiran serta pandangan. Tetapi yang tidak dapat disangkal ialah bahwa beberapa nilai pokok dari demokrasi konstitusionil

16 Titik Triwulan Tutik, 2010, Konstruksi Tata Negara Indonesia Pasca Amandemen UUD 1945, cet.1, Kencana Prenada Media Group, Hlm. 143

17 Janedri M. Gaffar, 2012, Demokrasi Konstitusional, Konstitusi Press, Hlm. 37 
cukup jelas tersirat di dalam UndangUndang Dasar 1945. Selain itu undangundang dasar kita menyebut secara ekplisit dua prinsip yang menjiwai naskah itu, dan yang dicantumkan dalam penjelasan mengenai sistem pemerintahan negara yaitu: ${ }^{18}$

1. Indonesia ialah negara yang berdsarkan atas hukum (rechtsstaat).

Negara Indonesia berdasarkan atas hukum (rechtstaat), tidak berdasarkan atas kekuasaan belaka (machtsstaat).

2. Sistim konstitusionil.

Pemerintahan berdasarkan atas sistim konstitusi (hukum dsar), tidak bersifat absolutisme (kekuasaan yang tidak terbatas). Berdasarkan dua istilah "rechtstaat" dan "sistem konstitusi", maka jelaslah bahwa demokrasi yang menjadi dasar dari Undang-Undang Dasar 1945, ialah demokrasi konstitusionil. Disamping itu corak khas demokrasi Indonesia, yaitu "kerakyatan yang dipimpin oleh hikmah kebijaksanaan dalam permusyawaratan perwakilan", dimuat dalam pembukaan undangundang dasar.

Demokrasi bukan hanya sistem pemerintahan saja, tetapi merupakan suatu gaya hidup, tatanan masyarakat tertentu dengan unsur-unsur moral, dan juga sekaligus demokrasi adalah nilai-

18 Titik Triwulan Tutik, 2010, Konstruksi Tata Negara Indonesia Pasca Amandemen UUD 1945, cet.I, Kencana Prenada Media Group, Jakarta, Hlm. 143 nilai. ${ }^{19}$ Bagir Manan menyatakan bahwa kehadiran demokrasi tidak sekedar diukur oleh keberadaan demokrasi pranata demokrasi, seperti keberadaan badan perwakilan, pemilihan umum bukanlah jaminan kehadiran demokrasi. Demokrasi bukan sekedar lembaga atau pranata. Demokrasi juga adalah mekanisme, bahkan tidak berlebihan apabila disebutkan, mekanisme yang demokratik merupakan penentu untuk mengukur kehadiran demokrasi yang rill, baik dalam kehidupan negara atau pemerintahan maupun kehidupan masyarakat pada umumnya. Secara kultural demokrasi akan subur bila ditopang oleh tingkah laku demokratik seperti kesiapan berbeda pendapat, kesiapan untuk kalah, kesiapan untuk bersaing secara jujur sikap damai dan lain-lain. ${ }^{20}$

\section{Kedaulatan Negara}

Menurut F. Isjwara dalam Ni'matul Huda menyatakan bahwa kata kedaulatan berasal dari kata sovereignty (bahasa Inggris), souverainete (bahasa Prancis) sovranus (bahasa italia). Kata-kata asing tersebut diturunkan dari kata latin superanus yang berarti "yang tertinggi" (supreme). Sarjana-sarjana dari abad menengah lazim menggunakan pengertian-pengertian yang serupa maknanya dengan istilah superanus itu,

\footnotetext{
${ }^{19}$ Syaiful Bakhri, 2010, Ilmu Negara; Dalam Konteks Negara Hukum Modern, Total Media, Jakarta, Hlm. 182

${ }^{20}$ Bagir Manan, 2001, Menyongsong Fajar Otonomi Daerah, PSH Fakultas Hukum UII, Yogyakarta, Hlm. 64 dalam Suharizal, Penguatan Demokrasi Lokal Melalui Penghapusan Jabatan Wakil Kepala Daerah, Jurnal Konstitusi, Volume 7 Nomor 5, Oktober 2010. Hlm. 97
} 
yakni summa potetas atau plenitude potestatic, yang berarti wewenang tertinggi dari suatu kesatuan politik. $^{21}$ Menurut Francis W. cooker dalam Ni'matul Huda, Istilah ini selalu berarti otoritas pemerintahan dan hukum. ${ }^{22}$

Menurut Goerge Jellinek bahwa hukum itu merupakan penjelmaan kehendak atau kemauan Negara. Karenanya negaralah yang menciptakan hukum, maka Negara dianggap satusatunya sumber hukum, dan negaralah yang memiliki kekuasaan tertinggi atau kedaulatan. Di luar Negara tidak ada satu orangpun yang berwenang menetapkan hukum. $^{23}$

\section{Kedaulatan Rakyat}

Berdasarkan teori ini, negara mendapatkan kekuasaan yaitu dari rakyatnya bukan dari tuhan atau raja. Hal ini yang pada awalnya menjadi latar belakang timbulnya pikiran baru yakni kedaulatan rakyat, ${ }^{24}$ disebut juga rakyat yang berdaulat.

Dalam terminologi ilmu politik modern, kata kedaulatan digunakan untuk mengartikan kemaharajaan mutlak atau kekuasaan raja yang paripurna. Kedaulatan memiliki hak yang tidak data diganggu gugat untuk memaksakan perintah-perintahnya kepada semua semua rakyat Negara yang bersangkutan

\footnotetext{
21 Ni'matul Huda, 2014, Ilmu Negara, Rajawali Pers, Jakarta, Hlm. 169

${ }^{22}$ Ibid. Hlm. 170

23 Soehino, Ilmu Negara, Liberty, Yogyakarta, Hlm. 155

${ }^{24}$ C.S.T. Kansil, Christine S.T. Kansil, 2005, Sistem Pemerintahan Indonesia, Bumi Aksara, Jakarta, HIm. 6
}

dan sang rakyat ini memiliki kewajiban mutlak untuk menaatinya tanpa memerhatikan apakah mereka bersedia atau tidak. Tidak ada media luar lainnya, kecuali kehendaknya sendiri, yang dapat mengenakan pembatalan pada kekuasaannya untuk memerintah. Tidak ada rakyat yang memiliki hak mutlak untuk melawannya atau bertentangan dengan perintah-perintahnya. Hak apapun yang dicabutnya akan dihapus. Sudah merupakan dalil universal di bidang hukum bahwa setiap hak hukum hanya tercipta jika pemberi hukum menginginkannya demikian. Oleh karenanya, jika sang pemberi hukum itu mencabutnya, keberadaannya dilenyapkan dan sesudahnya hak yang telah dihapuskan tersebut tidak dapat dituntut. Hukum tercipta melalui kehendak kedaulatan serta menempatkan semua rakyat negara dibawah kewajiban untuk menaatinya. Tetapi tidak ada hukum yang mengikat kedaulatan itu sendiri.

\section{Pengaturan tentang Organisasi Kemasyarakatan di Indonesia}

Penjabaran dari ketentuan Pasal-pasal yang tertera dalam UUD 1945 diantaranya adalah Pasal 28 Pasal $28 \mathrm{C}$ ayat (2), Pasal 28J Ayat (1) kemudian diturunkan ke dalam ketentuan UU No 17 Tahun 2013 tentang organisasi masyarakat yang diharapkan mampu untuk mendorong partisipasi aktif masyarakat dalam pembangunan dan tentunya yang berdasarkan Pancasila, karena Pancasila tidak hanya sebagai landasan dari seluruh peraturan perundang-undangan yang ada di Negara 
Indonesia, akan tetapi juga merupakan arah, cita-cita dan tujuan dari Negara Kesatuan Republik Indonesia.

Undang-Undang Nomor 17 Tahun 2013 sebagai suatu upaya untuk meningkatkan partisipasi aktif masyarakat yang diwujudkan dalam berbagai program kegiatan sosial kemasyarakatan dan kepemimpinan serta penyaluran aspirasi masyarakat. Hal itu juga menjadi salah satu dasar pengaturan dalam UU tentang Ormas yang secara sengaja menempatkan organisasi kemasyarakatan sebagai wadah partisipasi masyarakat dalam pembangunan. Melalui pengaturan dalam undang-undang, maka pelembagaan partisipasi masyarakat diharapkan dapat terlaksana dan memperoleh perhatian pemerintah karena berkaitan dengan aspirasi sejumlah orang dengan argumentasi yang kuat. ${ }^{25}$

Sebelum reformasi, keberadaan organisasi masyarakat diatur dengan Undang-Undang Nomor 8 tahun 1985 dan masih memakai Undang-Undang Dasar 1945 sebelum amandemen, karna tidak sesuai lagi dengan dinamika perkembangan masyarakat maka disusunlah Undang-Undang Nomor 17 Tahun 2013 untuk menggantikan. Pasca reformasi, organisasi masyarakat di Indonesia tumbuh subur, terbukanya kran demokrasi membuat masyarakat memiliki wadah yang lebih luas dalam

\footnotetext{
${ }^{25}$ Laporan Pengkajian hukum tentang Peran dan tanggungjawab Organisasi kemasyarakatan dalam pemberdayaan masyarakat, Pusat penelitian dan pengembangan sistem hukum nasional Badan Pembinaan hukum nasional, Kementrian hukum dan HAM RI Tahun 2011. Hlm. 4
}

menyampaikan aspirasinya salah satunya menyampaikan pendapat secara kolektif (kelompok) melalui organisasi.

Eksistensi organisasi bagi sebagian kalangan adalah suatu yang mengasyikkan, karena selain merupakan wahana tempat berkreatifitas, juga merupakan sarana penyaluran kehendak dan pemikiran yang baik dalam tatanan internal organissi, maupun dalam kerangka penyaluran kehendak dalam

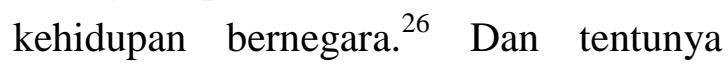
penyaluran aspirasi, kehendak, kebutuhan, kepentingan dan kegiatan yang dilakukan secara berkelompok tersebut tetap memperhatikan kaidah dan norma-norma hukum yang ada di Negara Indonesia karena demokrasi dalam konsep negara hukum adalah demokrasi yang bertanggung jawab dan tetap menghormati hak orang lain di sinilah keterkaiatannya dengan Hak Asasi manusia. Dalam negara hukum, demokrasi yang merupakan konsep penyelenggaraan negara hukum modern adalah yang tetap memiliki batasan undang-undang dalam penyelenggaraan negaranya. Keberadaan organisasi masyarakat selain sebagai perwujudan nilai-nilai demokrasi, juga merupakan perwujudan dari Hak Asasi Manusia.

\footnotetext{
${ }^{26}$ Laporan Pengkajian hukum tentang Peran dan tanggungjawab Organisasi kemasyarakatan dalam pemberdayaan masyarakat, Pusat penelitian dan pengembangan sistem hukum nasional Badan Pembinaan hukum nasional, Kementrian hukum dan HAM RI Tahun 2011, Hlm. 8
} 
Kedudukan

Organisasi

Kemasyarakatan asing di Indonesia ditinjau dari Peraturan Pemerintah Nomor 59 Tahun 2016 tentang Organisasi Kemasyarakatan yang didirikan oleh warga negara asing.

Peraturan Pemerintah Nomor 59 Tahun 2016 tentang Organisasi Kemasyarakatan yang didirikan oleh warga negara asing merupakan turunan dari Undang-undang Nomor 17 Tahun 2013. Dalam Undang-Undang Nomor 17 Tahun 2013 tersebut ketentuan tentang organisasi masyarakat yang didirikan oleh warga negara asing diatur dalam BAB XIII Pasal 43 - 52. Kemudian di atur lebih lanjut dalam Peraturan pemerintah Nomor 59 Tahun 2016 yang merupakan peraturan pelaksana dari Undang-Undang Nomor 17 Tahun 2013 semakin mengukuhkan legalitas keberadaan ormas asing di Indonesia.

Keberadaan ormas asing yang dikukuhkan dengan Undang-Undang Nomor 17 Tahun 2013 dan di kuatkan dengan keluarnya Peraruran Pemerintah Nomor 59 Tahun 2016 membuat masyarakat mengkhawatirkan terjadinya gangguan stabilatas keamanan negara. Memang hakikat keberadaan Organisasi Masyarakat adalah untuk mengakomodasi kepentingan masyarkat sebagai wadah aspirasi, ide, gagasan, gerakan, dan sebagainya dan memang dalam sejarahnya memang keberadaan Organisasi masyarakat memberikan konstribusi yang cukup besar bagi NKRI, mulai dari zaman Pergerakan dengan berdirinya Boedi Utomo, yang merupakan cikal bakal organisasi masyarakat yang pada akhirnya melahirkan semangat persatuan dan kebersamaan sehingga Negara Indonesia bisa berdiri tegak hingga hari ini.

Sejak sebelum Indonesia merdeka, kebebasan berserikat dan berkumpul serta membentuk berbagai organisasi merupakan bentuk perjuangan bangsa untuk mencapai kemerdekaan yang dimulai dengan Pembentukan organisasi Budi Utomo pada tahun 1905 yang merupakan tonggak awal perjuangan bangsa untuk mengusir penjajah. Kemudian hal tersebutlah yang menjadi cikal bakal pembentukan organisasi lainya di Indonesia termasuk organisasi islam diantaranya

Persyarikatan Muhammadiyah, Nahdlatul Ulama (NU), Persatuan Islam (Persis) dan menjadi sarana dalam menghimpun dan memberdayakan masyarakat. ${ }^{27}$ Tidak dapat di pungkiri bahwasanya keberadaan Organisasi masyarakat sebetulnya memang memiliki tujuan-tujuan yang mulia.

M. Billah dan Abdul Hakim G. Nusantara mengatakan bahwasanya adanya organisasi masyarakat merupakan bentuk telah adanya kesadaran golongan masyarakat menegah terhadap masalah kemiskinan, ketidak adilan sosial dan masalah HAM. $^{28}$ Namun, memberikan

\footnotetext{
27 Naskah Akademik Undang-Undang Nomor 17 Tahun 2013 tentang Organisasi Masyarakat

${ }^{28}$ Laporan Pengkajian Hukum Tentang Peran Dan Tanggungjawab Organisasi Kemasyarakatan Dalam Pemberdayaan Masyarakat, Pusat Penelitian Dan Pengembangan Sistem Hukum Nasional Badan Pembinaan Hukum Nasional
} 
ruang kepada Orang asing secara bersama-sama untuk mendirikan organisi masyarakat yang tidak memahami tentang Pancasila yang merupakan arah penyelenggaraan negara serta perundangundangan, ditambah dengan budaya masyarakat adalah sangat berbahaya bagi keamanan juga kedaulatan negara. Di samping itu, masing-masing organisasi memiliki tujuan dan idiologi organisasi masing-masing, bagaimana kalau ternyata maksud dan tujuan mereka untuk mendirikan organisasi masyarakat adalah membawa misi terselubung yang berbahaya bagi NKRI.

Di samping itu jika kita kembali kepada Pancasila, pada pembukaan alinea ke 4 juga dikatakan negara melindungi segenap bangsa Indonesia, dan seluruh tumpah darah Indonesia muncul pertanyaan atas dasar apa sebetulnya pemerintah mensahkan Undang-Undang Nomor 17 Tahun 2013 dan Peraturan Pemerintah Nomor 59 Tahun 2016 ini. Sedangkan di negara Indonesia sendiri organisasi masyarakat lokal beberapa diantaranya dianggap meresahkan masyarakat dan menimbulkan anarkis bagaimana dengan organisasi yang didirikan warga asing yang dari segi idiologi negara berbeda, budaya berbeda, dan kepentingannyapun kita tidak tahu pasti.

Secara teknis, hal-hal yang diatur oleh Peraturan Pemerintah Nomor 59 Tahun 2016 adalah perizinan organisasi

Kementerian Hukum Dan Hak Asasi Manusia Ri Tahun 2011.Hal 4, tersedia di http://www.bphn.go.id/data/documents/pkj-20111.pdf masyarakat yang didirikan oleh warga negara asing dan sanksinya jika melanggar ketentuan yang berlaku, lebih tepatnya sanksi administrasi berupa: a. peringatan tertulis, penghentian kegiatan, pembekuan izin operasional, pencabutan izin operasional, pembekuan izin prinsip, pencabutan izin prinsip dan sanksi ke imigrasian sesuai dengan peraturan perundang-undangan yang berlaku. Dalam faktanya memang mengatur tentang bagaimana memberikan batasan administrasi terhadap organisasi masyarakat yang didirikan warga asing, namun ketentuan tersebut belumlah mampu menjadi jaminan keamanan negara.

\section{Pengaruh keberadaan Ormas Asing bagi Kedaulatan NKRI}

Terbukanya ruang bagi organisasi masyarkat yang didirikan oleh warga asing membuka ancaman kedaulatan terhadap NKRI. Meskipun keberadaan PP No. 59 Tahun 2016 memberikan batasan tentang perizinan akan tetapi adanya ketentuan dalam Pasal 47 ayat (2) butir (d) "salah satu jabatan ketua, sekretaris atau bendahara di jabat oleh warga negara Indonesia”. Ketentuan pasal ini memungkinkan jabatan ketua dari organisasi masyarakat asing juga di jabat oleh warga asing.

Jika mengacu kepada wawasan nusantara, semestinya internal bangsa yang harus diperkuat terlebih dahulu untuk mengantisipasi terjadinya ancaman, tantangan, hambatan dan gangguan dalam penyelenggaraan negara yang akan berdampak pada kehidupan bangsa, dalam 
artian jika itu organisasi masyarakat maka peran organisasi masyarakat di NKRI yang perlu diperdayakan lebih maksimal oleh pemerintah, bukan mengambil kekuatan dari luar NKRI karena dapat mengancam kedaulatan negara karena ormas yang didirikan warga asing bisa menjadi alat untuk memata-matai situasi dan kegiatan dalam negeri, karnanya ruang gerak asing mestinya dibatasi.

\section{SIMPULAN}

Jika mengacu kepada konstitusi tertinggi di negara Indonesia, keberadaan ormas tidak bertentangan dengan undangundang, bahkan merupakan salah satu bentuk perwujudan demokrasi. Akan tetapi pengambilan kebijakan hukum untuk membuka ruang yang selebarlebarnya perlu dipertimbangkan lebih serius lagi oleh pemerintah, karna keberadaan organisasi masyarakat asing dapat menganmcam kedaulatan karena memiliki idiologi yang berbeda. Jika mengacu kepada proses pembentukan hukum, keberadaan masyarakat selalu lebih awal dibanding dengan hukum. Dengan kondisi Indonesia yang multikompleks akan rentan sekali timbulnya organisasi yang berbeda idiologi. Keberadaan Peraturan pemerintah Nomor 59 Tahun 2016 yang merupakan peraturan pelaksana dari Undang-Undang Nomor 17 tahun 2013 semakin mengukuhkan legalitas keberadaan ormas asing di Indonesia yang membuat masyarakat mengkhawatirkan terjadinya gangguan stabilatas keamanan negara.
Diberikan ruang kepada warga negara asing untuk mendirikan organisasi masyarakat membuka peluang ancaman bagi kedaulatan negara. Karnanya pemerintah perlu meninjau ulang kembali ketentuan di dalam Undang-Undang Nomor 17 Tahun 2013 Tentang Organisasi Masyarakat dan Peraturan Pemerintah Nomor 59 Tahun 2016 Tentang Organisasi Masyarakat yang didirikan oleh warga negara asing. Sebaiknya pemerintah terlebih dahulu memperkuat internal bangsa bukan mencari bantuan dari luar.

\section{DAFTAR PUSTAKA}

\section{Buku}

Bagir Manan, Menyongsong Fajar Otonomi Daerah, PSH Fakultas Hukum UII, Yogyakarta, 2001, hal. 64 Janedri M. Gaffar, Demokrasi Konstitusional, Konstitusi Press, 2012.

C.S.T.Kansil, Christine S.T. Kansil, 2005, Sistem Pemerintahan Indonesia, Bumi Aksara, Jakarta.

Megawati, Ali Murtopo, 2006, Parlemen Bikameral dalam sistem ketatanegaraan Indonesia, UAD Press, Yogyakarta.

Miriam Bidiardjo, 2007, Dasar-dasar Ilmu Politik, PT Gramedia Pustaka Utama, Jakarta.

Ni'matul Huda, 2014, Ilmu Negara, Rajawali Pers, Jakarta.

Soehino, 2008, Ilmu Negara, Liberty, Yogyakarta.

Subandi Almarsudi, 2001, Pancasila dan UUD 1945 dalam Paradigma 
Reformasi, PT. Raja Grafindo Persada, Jakarta.

Titik Triwulan Tutik, 2010, Konstruksi Tata Negara Indonesia Pasca Amandemen UUD 1945, cet.I, Kencana Prenada Media Group, Jakarta.

Syaiful Bakhri, Ilmu Negara;Dalam Konteks Negara Hukum Modern, Total Media, Jakarta, 2010.

\section{Website}

Laporan Pengkajian Hukum Tentang Peran Dan Tanggungjawab Organisasi Kemasyarakatan Dalam Pemberdayaan Masyarakat, Pusat Penelitian Dan Pengembangan Sistem Hukum Nasional Badan Pembinaan Hukum Nasional Kementerian Hukum Dan Hak Asasi Manusia RI Tahun 2011, tersedia di http://www.bphn.go.id/data/docume nts/pkj-2011-1.pdf

Laporan Pengkajian hukum tentang Peran dan tanggungjawab Organisasi kemasyarakatan dalam pemberdayaan masyarakat, Pusat penelitian dan pengembangan sistem hukum nasional Badan Pembinaan hukum nasional, Kementerian hukum dan HAM RI Tahun 2011.hal 4 tersedia di http://www.bphn.go.id/data/docume nts/pkj-2011-1.pdf

Catur Wibowo dan Herman Harefa, URGENSI PENGAWASAN ORGANISASI KEMASYARAKATAN OLEH PEMERINTAH , Badan Penelitian dan Pengembangan (BPP) Kementrian Dalam Negeri tersedia https://media.neliti.com/media/publi cations/52270-ID-urgensipengawasan-organisasikemasyarak.pdf

Waspadai Ormas Asing, tersedia di http://www.republika.co.id/berita/ko ran/fokuspublik/16/12/30/oizqc625waspadai-ormas-asing http://www.voa-islam.com/read/politikindonesia/2016/12/19/47976/jokowi -tandatangani-pp-59/2016-tentangormas-yang-didirikanwna/\#sthash.34OxsMH0.dpbs

http://www.kemendagri.go.id/news/2016/ 12/20/pp-59-perketat-berdirinyaormas-asing-di-indonesia

https://news.detik.com/berita/d3379374/kemlu-ada-67-ormasasing-di-indonesia-per-akhir-2016terbanyak-di-jabar

\section{Jurnal}

Bagir Manan, Menyongsong Fajar Otonomi Daerah, PSH Fakultas Hukum UII, Yogyakarta, 2001,hal.64 dalam Suharizal, Penguatan Demokrasi Lokal Melalui Penghapusan Jabatan Wakil Kepala Daerah, Jurnal Konstitusi, Volume 7 Nomor 5, Oktober 2010.

Catur Wibowo dan Herman Harefa, Urgensi Pengawasan Organisasi Kemasyarakatan oleh Pemerintah, Jurnal Bina Praja, Volume 7 Nomor 1 Edisi Maret 2015. hlm.1 - 20 tersedia di www.unigal.ac.id/ejurnal/html/inde x.php?naon=1052 
Elwidarifa Marwenny, Engrina Fauzi, dan Jelisye Putri Cenery: Kedudukan...

Suharizal, Penguatan Demokrasi Lokal Melalui Penghapusan Jabatan Wakil Kepala Daerah, Jurnal Konstitusi, Volume 7 Nomor 5, Oktober 2010.

Putu Indah Prameswari, Studi Kasus Tentang Organisasi Masyarakat Dalam Pemilihan Gubernur Bali 2013 , tersedia http://journal.unair.ac.id/downloadfullpapers-jpm3247d10b50full.pdf e-Journal Ilmu Pemerintahan, 4 (1) 2016: 428-441 ISSN 2477-2631, ejournal.ip.fisip-unmul.org (C) Copyright 2016 